\title{
Working Lives of Youth in Poverty in Urban Argentina
}

\section{Gonzalo Assusa and Mariana Chaves}

\section{INTRODUCTION}

What characterizes those who work and live in poverty starting in adolescence or childhood? Is escape from poverty truly attainable? Which mechanisms, tools, and events make it possible to move away from a life trajectory of poverty, when employment alone is not enough to make this shift? What continuities or breakdowns can be identified in the trajectory in relation to the economic and political context, the events, and the available networks of assistance? Does labor beginning in childhood or adolescence accumulate disadvantage? Why and how? How do working conditions influence this dynamic? How is it influenced by gender? And finally, how does the symbolic dimension articulate itself as the creator of differences and inequalities among working and poor adolescents and young people?

G. Assusa $(\bowtie)$

IDH-CONICET-UNC, Córdoba, Argentina

M. Chaves (四)

CONICET, Facultad de Trabajo Social, Universidad Nacional de La Plata, La Plata, Buenos Aires, Argentina

e-mail: mchaves@fcnym.unlp.edu.ar

(C) The Author(s) 2019

M. E. Rausky, M. Chaves (eds.), Living and Working in Poverty in Latin America, Governance, Development, and Social Inclusion in Latin America, https://doi.org/10.1007/978-3-030-00901-4_4 
While some of these opening questions may seem impossible to answer, they challenge us to consider a range of angles, seeking to understand not only the lives of working children and adolescents in poverty and the phenomenon of working in poverty throughout the life course but also the design of policies to reduce inequality and bring greater dignity to the lives of individuals. The inconsistencies in confronting the issues of poverty and work - previously analyzed in the introduction of the book-are explored again in this chapter. Located in Argentina, our analysis centers on how people between 15 and 24 years old work and live in poverty. These young people have several years of working experience, since most of them began working during childhood or adolescence and are part of families-both nuclear and extended-with low incomes.

Methodologically, this text is based on complementary fieldwork by the two authors. Chaves' fieldwork was carried out in a suburban neighborhood of the city of La Plata (Province of Buenos Aires), and Assusa's fieldwork was done in different neighborhoods of the city of Córdoba Capital (Province of Córdoba). ${ }^{1}$ Both conducted interviews and kept records of participant observation. Permanent Household Survey (PHS $)^{2}$ data were used for population analysis, including an initial characterization of the situation of working and poor youth in Argentina. The same data allowed us to make diachronic (over a period of time) and synchronic (regarding differences and inequalities among social classes) comparisons, to enable readers from other regions to understand the major trends in social conditions in Argentina. The richness of combining both data records and the complementary nature of quantitative and qualitative results provide a much wider framework for interpreting the phenomenon under analysis.

The interpretations that we make in this chapter are part of the tradition of researchers in the field of inequality study (Dubet, 2015; Goldthorpe, 2012; Reygadas, 2004; Therborn, 2015; Tilly, 2000), about life courses in general (Elder, 1994, 1998; Elder, Kirkpatrick, \& Crosnoe, 2003), and for Latin America (Bayón, 2015; Mora Salas \& de Oliveira, 2014; Saraví, 2009, 2015), in Argentina about social mobility (Bendit \& Miranda, 2015; Busso \& Pérez, 2016; Chávez Molina \& Pla, 2013; Espinoza \& Kessler, 2003; Salvia \& Lindenboim, 2015), about youth's trajectory and work (Balardini \& Miranda, 2000; Jacinto, 2002; Jacinto, Wolf, Bessega, \& Longo, 2005; Miranda \& Arancibia, 2017; Pérez \& Busso, 2014, 2015; Piecke Goicochea, 2001); and about poverty, youth, and work (Assusa, 2017; Chaves, 2014a; Chaves, Fuentes, \& Vecino, 2016; Efron, 
Konterllnik, \& Jacinto, 1996; Gallart, 2001; Macri \& Van Kemenade, 1993; Saraví, 2006, 2015), to mention only the main areas for engaging in dialogue with the purpose of providing some answers on this issue.

This chapter is organized in four sections that allow us to show structural trends, peculiarities, and symbolic disputes in the accumulation of disadvantage and the construction of inequality networks. Following the Introduction, the second section uses statistical data to provide a portrayal of the living and working conditions of young men and women. The third section focuses on three trajectories analyzed from the life course perspective (Elder, 1994; Mora Salas \& de Oliveira, 2014). Finally, the concluding discussion reexamines the opening questions in light of results obtained, public policies, and the 2030 Agenda for Sustainable Development.

\section{Youth, Work, and Poverty in Argentina: Statistical DATA AS A TOOL FOr INTERPRETATION}

The period in Argentina between 2003 and 2015 presents complexities and opposing trends ${ }^{3}$ : in different areas and dimensions of social lifefrom the labor market and income distribution to health, education, and access to land-social inequalities have tended to reconfigure and reproduce themselves or reduce their gaps in dissimilar ways (Kessler, 2014). However, in analytical terms, this period can be interpreted as one of relative coherence and directionality. Views vary with regard to the labor market dynamic in the years previously mentioned (Benza, 2016; Palomino \& Dalle, 2012; Quartulli \& Salvia, 2012; Vera, 2013). However, there is certain agreement that this period is characterized by a discontinuity of the neoliberal model pursued during the 1990s and the remarkable contraction of workforce demand in that period.

After the crisis of 2001 and the devaluation of the national currency, a combination of measures led to a reorientation toward economic recovery, mainly deploying the fixed productive capacity that had remained inactive during the period of convertibility, leading to a considerable increase in the demand for unskilled labor during the first years of the postconvertibility period. ${ }^{4}$

The period beginning in 2003 saw unemployment and poverty reaching their highest levels in the country's history, with unemployment finally settling below $10 \%$ for almost all of 2015 , with a progressive tendency to decrease, including during the years when job creation came to a standstill. Intergenerationally speaking, while the overall unemployment was on the 
decline, the differences between the unemployment indexes of young people (15-24 years old) and adults (25-64 years old) remained relatively stagnant over the entire period. The proportional relationship between unemployment in the two groups is about $2: 1$. This constitutes a worldwide trend, considered a public concern by international organizations (ILO, 2012, 2013).

Discussions around the dimensions of poverty are more complex: the Argentinian government's official poverty statistics have been a topic of considerable political dispute in recent years, their estimation being impugned, defended, and reconsidered by different sectors. ${ }^{5}$ However, focusing on young people from poor families requires abandoning the statistical naivety that considers an age category ("youth") as a homogeneous collective. At the same time, it also requires moving away from a common epistemological position in public policy against poverty, which asserts that social exclusion, marginalization, and vulnerability can be eliminated simply by integration into the labor market while neglecting to consider the more complex forces behind the lack of material and symbolic resources in poor families. Because of this, we consider it necessary to show not only the unequal way unemployment affects young people at different positions within the social structure but also the variable nature of integration into a highly stratified labor market and its implications for access to social security systems.

Discussion about the complexity and multidimensionality of social inequalities is extensive in the social sciences, and an examination of the methodological disputes over the operation of an empirical construction of inequalities would make for an entire article in its own right. With a view to establishing certain parameters of international comparison and the aim of favoring critical dialogue with researchers from the greatest theoretical spectrum possible, we collected data considering the per capita income in families of young people between 15 and 24 years old as a stratified variable.

Stratification studies and social inequality enable categorizing individuals and families into specific social classes in a variety of ways. The classic perspectives on stratification, based on different theoretical frameworks (Crompton, 1997; Rivas Rivas, 2008), consider the socio-occupational category of heads of household as the closest proxy to the position of the agents in production relationships and, therefore, to their class position. Other research and reports published by international organizations have considered money income as the main inequality variable, due to the ease of using a numerical variable for these characteristics (Ferreira et al., 2013). 
Considering that our research is not exclusively quantitative, we show some statistical trends on inequalities affecting young people by grouping them together according to their per capita income. Using the national PHS $^{6}$ for the second trimesters of 2004 and 2015, we grouped together the $30 \%$ of cases with the lowest income, the $10 \%$ of cases with the highest income, and the cases in between. In this way, we show how both advantages and disadvantages are unequally distributed and the way this uneven distribution represents a cumulative historical trend that has determined the strategies and experiences of young people and their families in the world of work (Saraví, 2009). Using these trends as a framework for interpretation, in the next section, we aim for a qualitative reconstruction of a number of specific life stories, exploring the articulation between the life courses, cumulative disadvantage, positions, trajectories, and class conditions of those young people who form part of the poorest $30 \%$.

But first, we will analyze the resource distribution and the work-related "issues" among young members of families with different and unequal incomes. First, we address the major differences in unemployment rates, inactive population, and kinds of inactivity. This will enable us to see some initial trends in terms of labor participation and the care economy, to provide greater understanding of the issues surrounding this text. Then we will analyze data on medical coverage, social security enrollment, establishment size, job qualifications, and the use of technology to show the degree to which, even among those employed, the wide range of conditions, opportunities, remuneration, and protections available through work are highly unequal.

As shown in Table 4.1, even though unemployment decreased in every income group, youth from low-income families remain almost five times more likely to be unemployed than their high-income counterparts. To be

Table 4.1 Unemployed and inactive population among young people (aged 15-24) according to income group (2004-2015)

\begin{tabular}{|c|c|c|c|c|c|c|}
\hline & \multicolumn{2}{|c|}{ Group of low incomes } & \multicolumn{2}{|c|}{$\begin{array}{l}\text { Group of medium and } \\
\text { medium-high incomes }\end{array}$} & \multicolumn{2}{|c|}{ Group of high incomes } \\
\hline & 2004 & 2015 & 2004 & 2015 & 2004 & 2015 \\
\hline $\begin{array}{l}\text { Employed (from } \\
\text { actives) }\end{array}$ & $59 \%$ & $75 \%$ & $74 \%$ & $85 \%$ & $87 \%$ & $94 \%$ \\
\hline $\begin{array}{l}\text { Unemployed } \\
\text { (from actives) }\end{array}$ & $41 \%$ & $25 \%$ & $26 \%$ & $15 \%$ & $13 \%$ & $6 \%$ \\
\hline $\begin{array}{l}\text { Inactive (from } \\
\mathrm{AEP} \text { ) }\end{array}$ & $58 \%$ & $73 \%$ & $56 \%$ & $66 \%$ & $54 \%$ & $55 \%$ \\
\hline
\end{tabular}

Source: Authors' own elaboration based on data from PHS 2004 and 2015 
clear, unemployment is much lower in 2015 than in 2004. The context of integration in recent years is much less marked by the crisis and desperation among young people seeking workforce integration. However, as the life courses analyzed in the next section will show, unequal exposure to rejection and exclusion in the search for employment is a recurring theme throughout these years.

For the approach that we suggest, it is also necessary to consider the proportion of the so-called inactive members of this age group: while much less unequally distributed than unemployment, inactivity also affects mainly young people with low incomes, and particularly young women.

Focusing on this trend, Table 4.2 reveals that inactivity due to concentration on domestic labor ("housewife") among young people from lowincome families is three times higher than the percentage of the same category among young people from high-income families. This trend leads - in relational terms - to a greater number of young people from poor families excluded from the labor market (whether unemployed or inactive); within this group, there is higher exposure to the type of activities that do not involve resource accumulation (such as obtaining educational credentials) that might "improve" the possibilities of labor integration in the future: many of them are young people outside of both paid employment and training practices.

In this way, we can evaluate how poverty exposes young people (but mainly young women) to much more complex choices and articulations than merely the choice between "studying or working." This can also be perceived through the unequal configuration of families. The average number of members under 10 in low-income families is almost ten times higher than the same average in high-income families. If we also consider the income differential, both the possibilities of attending domestic

Table 4.2 Type of inactivity for economically inactive young people (aged 15-24) according to income group (2004-2015)

\begin{tabular}{|c|c|c|c|c|c|c|}
\hline & \multicolumn{2}{|c|}{ Group of low incomes } & \multicolumn{2}{|c|}{$\begin{array}{l}\text { Group of medium and } \\
\text { medium-high incomes }\end{array}$} & \multicolumn{2}{|c|}{ Group of high incomes } \\
\hline & 2004 & 2015 & 2004 & 2015 & 2004 & 2015 \\
\hline Student & $69 \%$ & $70 \%$ & $83 \%$ & $82 \%$ & $92 \%$ & $87 \%$ \\
\hline Housewife & $19 \%$ & $16 \%$ & $11 \%$ & $10 \%$ & $5 \%$ & $6 \%$ \\
\hline
\end{tabular}

Source: Authors' own elaboration based on data from PHS 2004 and 2015 
demands (such as by hiring a care assistant) and the dimension of these chores (the number of people in the house requiring care) make this activity much more arduous in low-income homes, due to the need for more working hours and/or human energy to attend the domestic management of a greater number of people.

As we have seen in a substantial part of our fieldwork, the care economy is a significant part of women's life since childhood: the unequal distribution of chores among siblings depending on their gender becomes broader as they grow older, encroaching into adolescence, and youth (Hernandez, Cingolani, \& Chaves, 2015). Additionally, young women's work taking care of their siblings is frequently replaced-or overlapped-by taking care of their own children. Finally, the practical knowledge accumulated due to involvement in domestic chores within their own family develops, in many cases, into a resource for labor integration: many of young women's first employment experiences involve taking care of young children and older adults, in combination with cleaning tasks and related activities.

In this way, the trajectories of poor young people must constantly articulate between "studying," "working," and "providing care," depending on the cycles of accumulation and economic restriction within their families.

At the same time, even though period from 2003 to 2015 is characterized by an increase in formal employment among dependent workers, Table 4.3 reveals a similar process to the one observed in unemployment: informality decreased in every income group among young people, but it maintained an unequal structure that keeps more than the half of lowincome young people in the informal sector (in comparison to a fifth of

Table 4.3 Social security indicators among young people (aged 15-24) according to income group (2004-2015)

\begin{tabular}{|c|c|c|c|c|c|c|}
\hline & \multicolumn{2}{|c|}{ Group of low incomes } & \multicolumn{2}{|c|}{$\begin{array}{l}\text { Group of medium and } \\
\text { medium-high incomes }\end{array}$} & \multicolumn{2}{|c|}{ Group of high incomes } \\
\hline & 2004 & 2015 & 2004 & 2015 & 2004 & 2015 \\
\hline $\begin{array}{l}\text { Without health } \\
\text { coverage }\end{array}$ & $73 \%$ & $62 \%$ & $41 \%$ & $29 \%$ & $14 \%$ & $9 \%$ \\
\hline Informal & $95 \%$ & $62 \%$ & $66 \%$ & $46 \%$ & $41 \%$ & $19 \%$ \\
\hline $\begin{array}{l}\text { Work in places } \\
\text { of more than } \\
40 \text { people }\end{array}$ & $19 \%$ & $18 \%$ & $17 \%$ & $26 \%$ & $28 \%$ & $36 \%$ \\
\hline
\end{tabular}

Source: Authors' own elaboration based on data from PHS 2004 and 2015 
high-income young people in the same situation). The smaller numbers of poor youth working for large employers (which, according to conventional wisdom, are considered to be the most subject to state oversight and, consequently, less inclined to be involved in the informal labor market) also offer evidence of the same dynamic.

While the sphere of employment activity does not of itself determine working conditions beyond hierarchies and job posts, the unequal distribution between spheres has significance for labor contexts with very disparate trends regarding the level of macroeconomic activity and the precariousness of job posts. While some areas like industry and commerce hold great influence over youth employment, their distribution by income group is rather homogeneous. Other areas, however, such as public administration, have a strong association with the high-income group, while domestic service and the construction sector are statistically associated with low-income young people. The last areas mentioned are characterized by a lack of job security as regards contract duration, formality of the job, and wages (Fernández Massi, 2014). According to 2016 data from the National Institute of Statistics and Census of Argentina (INDEC), the rate of informality in domestic services exceeds $74 \%$, while in construction it exceeds $68 \%$. As will be shown in later sections, the decisive step into these areas leaves an indelible imprint on the work experience of youth from poor families, with the appreciation and valuation systems specific to these spheres coming into play throughout their trajectories. What is more, their experiences in construction and domestic services are essential for practical job training and for understanding both the intergenerational relationship that regulates and articulates activities (work/care work) within their families.

The figures referring to health coverage in Table 4.3 point out a complementary process that feeds this trend. Despite the fact that the number of young people without health coverage decreased in every income group during the period from 2004 to 2015 , it decreased to a lesser extent in the low-income group than in the medium- and high-income groups. This is due mainly to the ability of the family as a whole to access these kinds of resources: during this period, adults from medium- and high-income families were incorporated at much higher rates into formal employment, the main means of access to social security and worker protections, thereby benefiting their entire families. Meanwhile, not only young people but also adults from low-income families remained much more exposed to informal labor integration without social security during this period. 
Table 4.4 Characterization of job posts among employed young people (aged 15-24) according to income group (2004-2015)

\begin{tabular}{|c|c|c|c|c|c|c|}
\hline & \multicolumn{2}{|c|}{ Group of low incomes } & \multicolumn{2}{|c|}{$\begin{array}{l}\text { Group of medium and } \\
\text { medium-high incomes }\end{array}$} & \multicolumn{2}{|c|}{ Group of high incomes } \\
\hline & 2004 & 2015 & 2004 & 2015 & 2004 & 2015 \\
\hline $\begin{array}{l}\text { Computer } \\
\text { equipment and } \\
\text { system } \\
\text { operation }\end{array}$ & $0 \%$ & $2 \%$ & $2 \%$ & $10 \%$ & $5 \%$ & $26 \%$ \\
\hline Qualified & $35 \%$ & $43 \%$ & $47 \%$ & $51 \%$ & $52 \%$ & $66 \%$ \\
\hline Unskilled & $61 \%$ & $51 \%$ & $42 \%$ & $38 \%$ & $18 \%$ & $14 \%$ \\
\hline $\begin{array}{l}\text { Less skilled } \\
\text { positions }\end{array}$ & $96 \%$ & $94 \%$ & $89 \%$ & $89 \%$ & $70 \%$ & $79 \%$ \\
\hline
\end{tabular}

Source: Authors' own elaboration based on data from PHS 2004 and 2015

Finally, if we consider only employed youth in each income group, we can see that (Table 4.4), even though there was a generalized process of improvement in job qualifications (i.e. growth in operational and professional positions), the number of low-income young people in unskilled jobs is three times higher than the number of high-income young people; also, the use of computer equipment and systems in their jobs is ten times lower than that among high-income young people. This implies participation in production areas with lower added value, with less-recognized job skills, and, consequently, lower remuneration and rewards of every kind in these positions.

To sum up, even when they are employed, low-income youth remain more exposed to precarious conditions, stigmatization, multiple kinds of pressure and demands (such as the pressures of care obligations), and exclusion from social security and worker protections, largely without access to resources through their families (such as health coverage).

Disadvantages related to their job positions are accumulated over the life courses of these young people, partly because their integration into precarious areas of the labor market is driven by a history of informal labor situations within their families. An individual's position in the social space according to his or her job post can be a factor in overcoming disadvantage, but it can also be completely the opposite: a continuity of disadvantages accumulating to the point where it becomes very difficult to curb the trend. The next section presents a number of life courses, highlighting both heterogeneity and regularity in these experiences. 


\section{Trajectories in Poverty \\ Conditions and Work Experiences}

The life stories of Yamila, Antonio, and Abel will help us show the reproduction strategies (Eguia \& Ortale, 2004; Eguia, Ortale, Piovani, \& Weingast, 2007; Gutiérrez, 2007, 2015) of the families where they grew up and their work experiences up to the present. Throughout their lives, these young people have belonged to the low-income sector of the population. Now they are between 18 and 24 years old and, in occupational terms, they would be described as an economically active population: at the time of writing, all three of them were informally employed in precarious jobs. ${ }^{7}$

Writing "low incomes" brings to mind the story of Yamila- a young woman who is now 23 with 2 children -who 8 years ago used the words, "so poor that you don't even have one peso," to describe life conditions when she was 15 and responsible for her 4 siblings. The expression "poor, as always" also comes to mind; it is used by Alicia Gutiérrez (2015) in her classic book of the same title. These two expressions carry two meanings that weave a single thread throughout this chapter: on one hand, the role of family relationships, and on the other hand, the history, the temporality of life in poverty.

Poverty as a relational condition is about the unequal distribution of innumerable resources, including devices, property, rights, opportunities, strategies, or even the very language used to describe distribution, dispute, or existence. The truth is that the relationship between access and hardship represents a sharp division in society-between malnourishment, exposure to cold, substandard living conditions, lack of toys, the inability to go to school, lack of access to quality medical care, the obligation to care for siblings or children, and not experiencing any of these situations. These descriptors, in addition to those listed in the first section of this chapter-as well as others to be outlined further on-allow us to place the individuals and their families within the social space in order to learn how they "managed" to survive in poverty over time and how they started working from an early age in order to achieve this. It is essential to know what jobs they did and their working conditions, as well as acknowledge subjects' capacity for agency, their networks, and the state or non-state support they were able to access or create.

\section{ramila}

Yamila was born in the province of Misiones, in a town where the main activity is the cultivation of yerba mate; she describes it as "a place where 
people help each other" and adds "everybody is poor there, there aren't people with money like here." A few years later, her mother decided to separate from her father and they moved to the city of La Plata to live in the neighborhood where she was living when we talked to her. Even though this family migratory movement is one of the first crucial moments in her trajectory, there is another which she considers to be the most relevant, which represented a turning point in her life and forced her to grow up very suddenly. At the time, she was one of six siblings, the oldest of whom had stayed behind in Misiones. The youngest was two months old when the mother decided to leave the neighborhood on her own, leaving Yamila with all care responsibilities (the mother came back approximately two years later and left again several times): "from that day on I had to take on the role of the absent adult, and I was 8 years old." She threw herself into caring for her siblings, who were now her responsibility. She started working in the house of a neighbor, first running errands and then doing cleaning jobs; after a while she abandoned primary school. "I couldn't deal with everything, one day I stopped going; then, so did Osvaldo, and later, so did Marcelo," she said, referring to the brothers who followed her chronologically. Only the two youngest siblings stayed in school. They supported themselves by means of multiple strategies: Yamila's work (which continues into the present in a variety of jobs), her brother's occasional employment, help from neighbors, social programs, and integration into a social organization with community centers for babies, children, and young people. These state and community support systems and these children and adolescents' own capacity for agency made possible their survival without being institutionalized.

Yamila's trajectory from an early age set her on a continuous course of cumulative disadvantage. She never stopped working, except during certain weeks or months when she was unemployed. However, all her jobs have been in the informal sector without access to social security; consequently, despite having 15 years' work experience, she has been unable to participate in the retirement system, health coverage, workplace accident insurance, or have access to any other benefit available to some employees (e.g. unionization, loans, co-insurance, among others). Her jobs have included running errands, cleaning houses, attending clients in a pizza kitchen, sweeping the streets and plots of the city, assisting nurses, and finally, her current job, taking care of a sick elderly lady. However, her path has allowed her to accumulate certain kinds of capital. First, as social capi- 
tal, she benefits from relationships with neighbors and with the social organization where she is a participant. Her economic capital consists of the lot where she has lived as a squatter with her mother and her siblings, as well as the fruits of the different income transfer programs which she has strategically articulated to obtain a little more money with each successive month. Thirdly, as cultural capital, she has studied to become a nursing assistant in a public hospital. Despite having all this experience at just 23 years old, Yamila is still living in poverty. Now she has two young children, she rents a house for the three of them in the same neighborhood, and she is able to support her family with the money she earns as a care worker (informal skilled paid work), together with the payments she receives from social programs $\left(A U H,{ }^{8}\right.$ Plan Más Vida,${ }^{9}$ and a municipal contribution by the childhood and adolescence department) and the aid from the social organization in which she still participates.

\section{Antonio}

Antonio graduated from a public high school near his home and is one of the few in the neighborhood to achieve this milestone despite experiencing homelessness during several periods of his life. He was born and raised in the same place. He did not have much to eat and was often exposed to the cold. He lives with his mother and is the oldest of three siblings. While at school he was supported by his mother, by a social organization he has attended since he was a child, by an income transfer program $(A U H)$, and, of course, by his own determination. All of his siblings are still in school, although one of them has attended intermittently since he started high school.

Living conditions have been hard for the family: they live as squatters on a plot which they share with an uncle and his family; it has flooded on occasion and the building, fragile at first, can now be considered vulnerable, and it has always been small. Antonio's mother has always had intermittent and precarious jobs. She experienced gender-based violence at the hands of one of her partners, also causing Antonio to experience family violence. Continuing his education was connected to his strong desire to obtain a "formal" job and to turn that schooling capital into economic capital. However, that goal has not yet been achieved-by enrolling in the police force or armed forces as Antonio had planned-since he was rejected by both of them.

Antonio started working outside his home when he was 16 years old. He used to be partially responsible for taking care of his siblings and the 
house, as well as searching the neighborhood for clothes and food from churches, soup kitchens, and organizations. He started working in a refrigerator repair shop, but received hardly any money and eventually grew fed up: “it was unfair, I didn't even get one peso." A variety of different jobs followed, all of them precarious, inconsistent, and sporadic: as a gardener, builder's apprentice, and painter. At the community organization, he acquired informal training in graphics; despite some difficulties, he completed his training and started working at the printing house run by the same NGO. Like Yamila and 95\% of low-income young people, he has no social security because he has never had formal employment (see Table 4.3). Antonio made a classic bet on schooling, an investment that has not yet brought returns, and neither his family trajectory nor the labor market have provided the structural conditions necessary for obtaining such a return. Now 20, he still lives with his mother and siblings. Antonio and his mother combine their incomes and some occasional contributions from the father of his siblings, together with money transfers from social programs (AUH, Plan Más Vida) and the aid of a social organization (clothes, food, mediation with government agencies, educational and recreational activities for children and young people).

\section{Abel}

The third life story is Abel's. He was born and raised in the neighborhood where he lives with his mother, his father, and four younger siblings in a house made of wood and cement with repairs made of cardboard and nylon. He completed up to the penultimate year of high school, but dropped out after failing a number of classes. He plans to finish school someday "because the certificate is good to have," he tells us, revealing his hope of overcoming the accumulation of disadvantages keeping him down. His mother is his role model, having finished her own high school through the FinEs $2^{10}$ program. Reproduction strategies in the family's home combine the income earned by his father, who works in construction, with his mother's work in the house and the raising of the children, as well as social program benefits ( $A U H$, Más Vida), donations of clothes and food by neighbors, and income from Abel's own work.

At the age of 12-the same time he started high school-he began working in a neighborhood bakery: "I cleaned sheet trays the whole morning after baking." He was paid very little, but "you couldn't get many other jobs at that age." It lasted "around two years." Many other times he 
helped his father working as his builder's assistant; in that job he sometimes earned his own money, but at other times it was his father who received all the money, which was used for the household. There were times when he did not work, but the need to do so always existed: "I had to work to help my family, or, at least, get money to meet my expenses." He became interested in the esthetic production on the body, such as piercings and tattoos, and he approached the field by learning the profession with the help of an older tattooist. He started investing in equipment and inks with what money he could save from odd jobs, until he equipped himself with working tools and clients. Now he is 18 and works as a freelance tattooist, as well as working a number of other informal jobs.

As mentioned before, Yamila, Antonio, and Abel are part of the "lowincome" group of the population characterized in statistical terms in the previous section, where we could visualize differences by income regarding inequality in employment opportunities, categories of inactivity, access to social security, and job characteristics (see Tables 4.1, 4.2, 4.3, and 4.4).

In order to make some general interpretations about the three storiesand somehow include many others that were not told here but share similarities with the ones presented-we will consider Mora Salas and de Oliveira's (2014) analytical axes, overtaking and deepening Elder's approach (1994): (1) family environment; (2) occurrence and timing of life events; (3) critical moments; (4) family, social, and institutional supports; and (5) choices, decisions, expectations, and future plans. This will enable us to identify the ways in which disadvantages are either accumulated or overcome, challenging the notion that work "per se" or "any" job is enough to achieve the eradication of poverty.

As regards the family environment, we are talking about domestic units who have been living in poverty for at least three or four generations (the earliest historical records only go this far, although this does not imply that people in general had better living conditions in the more distant past). Labor situations that contribute to this cycle include the scarcity of formal employment, low salaries-always-precarious working conditions, and the booming informal economy, which provides no access to social security. Labor informality is a constant in poor families. Yamila's grandparents live within a locally based agricultural economy in the Northwest of the country; her mother migrated to La Plata as an adult and transitioned her working trajectory from rural work to urban work in 
services. Some of Abel's and Antonio's grandparents were born in La Plata, while others also had their origins in the country's Northwest. The two men and their parents were born in the neighborhood where they continue to live to this day.

In previous research (Chaves et al., 2016), we showed how a family's "progress" and improvements in living conditions are structured around four elements: (1) Access to land and/or housing, measured by property, possession, and type of materials; (2) Access to infrastructure and services: electricity, water, gas, drains, pavement, transport, health, and education; (3) Integration into non-rural employment, greater occupational choices, better working conditions, and symbolically better-regarded jobs; (4) Access to public programs: social support, health, and education. The family and class trajectory conditions of the young men and women who participated in this research socialized them into a working environment from a young age which demands effort, physical strain, and working precariousness, as well as imposing gender-based social divisions in employment based on traditional gender roles. This reproduces the scheme of working outside the house for men and inside the house-or inside and outside-for women.

Argentina has seen an increase in the intergenerational accumulation of school-based qualifications. ${ }^{11}$ The families of these young people are no exception to this trend. While this accumulation of educational capital represents one way to overcome disadvantages, the case of Antonio, and that of many others, serves to illustrate that it is another thing entirely to translate this progress into economic gain similar to that achieved by youth at other income levels, with the search often ending in frustration. Yamila's situation is the bleakest, since she has not finished primary school. Many young people are in the same situation: their desire and intent to finish their schooling are genuine; however, they cannot find an institutional offering that fosters them or that might be compatible with their paternity or maternity situations and/or jobs.

The occurrence and timing of life events is the second axis of analysis. In the cases studied, we considered births, deaths, beginning of workforce participation, and union of partners as life events. The three cases described show an early entry into the workforce: their working careers outside their houses start when they are between 8 and 16, and if we include work done inside the home, it begins even earlier in two cases with the care of siblings, feeding the family, and house cleaning. The time spent taking care of others is a factor that produces significant inequality in comparison to 
children and young people from other social positions. There is an accumulation of disadvantage of several aspects: by obstructing schooling, influencing early processes of responsibility and autonomy, and narrowing of the possible spectrum of work opportunities (with job searches subordinated to the times that care work leaves available).

Yamila's life reveals the incidence of maternity as a life event. She imagined that the birth of her first child would mean emancipation from her mother, ending her responsibilities to care for her siblings and support her family: "I thought that if I had a child I would be able to leave and wouldn't have to support them anymore." But that autonomy came at the cost of further accumulation of disadvantage: she did not stop taking care of others, merely shifting from one subject of care to another, and she could not gain time "to go back to school" or "go out and have fun." Consequently, this life event appears to have had a double effect: on one hand, it had the positive result of overcoming the disadvantage of being subordinated to her mother and the achievement of economic and housing autonomy; on the other hand, it nonetheless contributes to the accumulation of disadvantages, since she is still left caring for others and supporting them economically.

Crucial moments constitute the third axis of analysis. Certain life events are also crucial moments, but that is not the case in any of the life stories told here. Yamila's own perception of the crucial moment that represents a turning point in her life was "becoming responsible for my sister." Her life and the lives of her siblings became disorganized and organized again due to her mother's departure. According to these young people's descriptions, fathers and/or mothers who do not take care of their children, either temporarily or permanently, produce crucial moments in their life trajectories. It is worth noting a gender-based difference in the perception of adults' roles, as the absence of the father is normalized, and therefore perceived more as a life event than a crucial moment (but, of course, not in every case). Such an idea is based on a patriarchal conception of whose responsibility it is to care for children, one which dominates the Western cultural matrix.

In relation to the fourth axis, support, we have previously established that family incomes are not only based on incomes, payments for work, money transfers, or benefits from social policies" ${ }^{12}$ but also on "contributions" by relatives and friends, as well as cultural, political, social, sportbased, and religious organizations. The focus of our research on young people in La Plata with ties to a community organization has made it pos- 
sible to study the influence of the organization, and some of its adult mentors, on the lives of these young people and on the reproduction strategies used within both their families of origin and their own families. Health and educational institutions are insufficient at the margins where society's poorest live their lives; they are characterized by crumbling infrastructure and often by negligent attention (Chaves, 2014b). Nonetheless, those who manage to attend and remain in school gain meaningful experiences and combine trajectories of "doing well" intermittently with "doing badly," possibly because of longer interruptions of schooling, as in Abel's case. Adult mentors who provide meaningful support also work in the areas of health, school, and sport, but universally the most influential support is that provided by the nuclear family and particularly the mother figure.

In our analysis of the three life courses, we have described situations and processes of accumulation and dispossession of capital. We have shown different positions within the social space and the variety of social roles performed by these young people in their daily lives. Drawing on these analyses, we could interpret some of the situations described as creating or eliminating advantages and disadvantages. Bearing in mind that these families are situated among the poorest 30\% of Argentinian families, the construction of trajectories in the analyzed sector shows heterogeneity, but also many recurring themes. The permanence in the role of workers is one constant; another, to be discussed below, is the representation of a hard life, based on a strong perception of effort, which contrasts with the idea held by many in Argentinian society about poor young men and women. What is described both by outsiders but also inside poor neighborhoods as laziness, apathy, or "ni-ni" (Spanish for a young person who "neither works nor studies") is translated in practice into a wide range of ways to combine work, study, and care work.

\section{CONCLUSION}

It may seem obvious, but given the current context, obvious does not mean unnecessary: labor market integration does not necessarily imply social integration into decent living conditions that reverse and overcome poverty. Different forms of exploitation and the inequality networks in which young people participate determine whether conditions of poverty worsen, stay the same, or are opened to real possibilities for change. The situations of the families and young people studied in La Plata and in Córdoba Capital are not exceptions among working class youth in large urban centers in Argentina, but rather the rule. 
Exposure to labor exploitation and a lack of decent wages are common themes in working class trajectories. Their activities are carried out in jobs and industries which are badly paid and, in many cases, poorly regarded by society. These jobs are informal and offer no health coverage, meaning that access to quality health services for this working population is limited, setting the foundations for precarious lives. As sustained by Therborn (2015) and Bravo Almonacid (2015), you live less when you are poor. Also, in a way, integration in the labor market starting in childhood or adolescence produces premature exhaustion of human energy. Moreover, when jobs do not provide payments into retirement programs, employees are left without the economic support of social security when they grow old. The endless cycle of precarious employment and the impossibility of moving out of the informal economy keep these young people, and usually their parents, for the most part, trapped within the most vulnerable positions in the social space.

The young people who participated in the research are imbricated in networks of inequality (Reygadas, 2004) that both reproduce their condition of poverty and their positions of subordination in various areas, as they allow to identify the youth agencies, "the efforts" (Saraví, 2009, Jacinto et al., 2005, Roberti, 2016; Chaves, 2016) and the strategies they carry out to live. ${ }^{13}$

Ways to get out of poverty do exist, but they do not depend exclusively or even mostly on the subjects. As we have endeavored to show throughout this chapter, the wide range of conditions, opportunities, rewards, and protection available through work are deeply unequal in nature and must be disclosed. This concept has been the driving force behind this research, for both the urban-based population analysis and the case studies of Yamila, Antonio, and Abel. Our focus has been on wage earners and occasional workers living in poverty, who come from families in the same situation, on trajectories pointing them toward a continuity or even a worsening of their condition. As such, while workforce participation is necessary, it is not sufficient on its own to produce decent living conditions. It has long been acknowledged that the "sale of labor" does not provide enough resources for its own reproduction. However, a substantial improvement in the conditions of the state's organization of care work could result in improvements in the lives of children, teenagers, and young men and women who take care of others. The same is true of the creation of protection systems for young and 
adolescent workers, which would also go a long way toward ending some of the effects of cumulative disadvantage.

Data on the strategies used by young men and women to combine care work, studies, and work allow us to conclude that, if certain disadvantages can be overcome, perhaps through obtaining access to basic rights and decent working conditions, a positive effect will be passed over into other areas. It is necessary to imagine, design, and implement measures that carry a real possibility of creating compatibility between the different social roles held by these young people: father, mother, student, worker, and care worker, among others. It is also important to bring recognition and validation to the role of poor young men and women in care work, as it represents a fundamental contribution to their families' reproduction strategies.

We would like to mention one more thing before making reference to the 2030 Agenda for Sustainable Development: the moral value of work and how work, "the attitude towards work," or "working culture" (Assusa, 2016; Chaves, 2016; Chaves et al., 2016) are used by several social agents to build a sense of moral belonging in communities. The young people studied here also do this-on one hand, by internalizing meritocratic dichotomies that distinguish between "hard working people and layabouts"; on the other, disputing the meaning for a positive recognition of their situation in the face of the classic stigma that young poor people do not work.

To sum up, in this chapter we have sought to contribute to the characterization of life courses of young people whose work trajectories began in childhood or adolescence and who live in poverty. We also intended to contribute to the visibility of work trajectories which, having started at childhood and in poverty, imply an accumulation disadvantage which cannot be reversed simply through blame or individual responsibility, fragmentary public policies, "the free market," destiny, or chance. In accordance with the United Nations' 2030 Agenda for Sustainable Development, we intend to spread knowledge that could influence the implementation of measures to fulfill those goals: zero hunger, no poverty, decent work and economic growth, and gender equality-to mention just 4 of the 17 goals. However, these cannot be achieved without a deep transformation in exploitative relationships and inequality networks in which the lives of the young people in this research take place-as well as all the other men and women who, like them, work hard and continue leading lives of poverty. 


\section{Notes}

1. Chaves' data about trajectory were collected in the context of a sociocommunity activity with young people, which included accompanying them through their lives and activities in a social organization. It was financed by National Scientific and Technical Research Council (CONICET) and National University of La Plata (UNLP) research grants and UNLP National Community Extension and Volunteering Activities and University Policies Office. Assusa's work is part of several research projects financed by the CONICET and National University of Córdoba.

2. The Permanent Household Survey (PHS) is the main statistical source in Argentina to monitor data related to socioeconomic and working indicators. It gathers information on urban centers, most of which have more than 100,000 inhabitants. This source is representative-taking necessary precautions - of a country like Argentina, which has more than $90 \%$ of its population in urban spaces. This must be taken into account if international comparisons are to be made, mainly in the Latin American region, where countries like Brazil, Mexico, and Bolivia have 14\%, $21 \%$, and 30\% of rural population, respectively (according to World Bank data from 2015).

3. The period 2003-2015 is defined as a time of neodevelopmentalist policies by several authors (O’Connor, 2009; Féliz, 2015, among others). The national government had the same political line: Peronism. The first presidency was Néstor Kirchner's (2003-2007), and then Cristina Fernández de Kirchner was president for two periods (2007-2015). In 2015, this administration was defeated in the polls by Mauricio Macri-whose party is called Cambiemos (alliance between Republican Proposal (PRO) and Radical Civic Union) — and a period of neoliberal policies began.

4. The period characterized by the "Convertibility Plan" in Argentina has to do with the monetary policy of the 1990s, which was developed during the presidency of Carlos Menem and the interrupted presidency of Fernando de la Rúa. The crisis of the neoliberal model in the country led to a complementary crisis of the political representation system in 2001, which only stabilized in 2003 due to the beginning of Néstor Kirchner's presidency, even though some of the specific policies coming out of the crisis had already started in 2002. Most of these measures implied returning to policies of economic deregulation and enormous flexibility in the labor market beginning in the 1990s. Because of the drastic modification that this change produced on economic policies and the dynamic of workforce demand, reconstruction of working policies, and distributive struggle, alternative categories are used to characterize a period difficult to describe: postconvertibility, postneoliberalism, neodevelopmentalism, and so forth. For further information about the characterization of the "project" that began in 2003, see Feliz (2012). 
5. In 2007 the national government took control over INDEC [Spanish for National Institute of Statistics and Census of Argentina] and modified the calculation of CPI. This rate, apart from being useful to analyze basic consumer goods and, consequently, the lines of poverty and extreme poverty, adjusted the payment of interest on the foreign debt. The manipulation of this rate was a significant topic of discussion for the public and the media and cast doubt on the transparency of the entire National Statistical System during the last years of presidency of the Victory Front bloc. A group of private studies analyzing the measurement of these figures became visible in recent years, among which the Argentine Social Debt Survey by the Catholic University of Argentina stands out. At the same time, it has been suggested that there was a certain manipulation in the unemployment figures, namely, a kind of search that checked cases of "dubious" activity or unemployment. The most critical estimate holds that the differences produced by these revisions may oscillate between $0.5 \%$ and $1 \%$.

6. The Permanent Household Survey (PHS) is the main statistical source in Argentina for monitoring data related to socioeconomic and working indicators. It gathers information on urban centers, most of which have more than 100,000 inhabitants. This source is representative-taking necessary precautions-of a country like Argentina, which has more than $90 \%$ of its population in urban spaces. This must be taken into account if international comparisons are to be made, mainly in the Latin American region, where countries like Brazil, Mexico, and Bolivia have 14\%, $21 \%$, and $30 \%$ of rural population, respectively (according to World Bank data from 2015).

7. For definitions and discussions about precarious and informal labor and jobs in Argentina, we suggest Beccaria, Carpio, and Orsati (2000), Battistini (2009), and Bertranou, Jiménez, and Jiménez (2013).

8. [Spanish for Universal Child Allowance]. It is a conditional income transfer program for underage ( 18 years old or less) people attending school, having medical checkups done, and whose parents have no formal or freelance work. For further information, see Social Security Observatory (2011).

9. A Conditional Cash Transfer Program financed by the State (State and Buenos Aires Province) which has maternity integration requirements (at least two children) and the lack of a formal work or freelance work. For more information, see http://planmasvida.com

10. "Fines2 Program (Spanish for High School Completion Plan) is a national policy, managed by provinces, whose objective is to guarantee the completion of high school education by young people and adults who could not do so for a number of reasons" (for further information, see Crego \& González, 2015: 3). 
11. Information can be found in the Information System on Educational Trends in Latin America (SITEAL, IIPE-UNESCO, http://www.siteal. iipe-oei.org) and in the National Department of Information and Assessment of Educational Quality (DINIECE), Ministry of Education: http://portales.educacion.gov.ar/diniece/

12. In the analyzed period, we identified a positive impact caused by the Universal Child Allowance income transfer policy, Provisional Inclusion Plan (Bravo Almonacid, 2015), and the policies related to work cooperatives in urban maintenance administrated by the State and municipal authorities (Crego \& González, 2015).

13. See chapters in this book about Argentina written by María Eugenia Rausky, focusing on children and teenagers, and by Débora Gorbán and Ana Tizziani, dealing with paid women domestic workers.

\section{BIBLIOGRAPHY}

Assusa, G. (2016). La 'cultura del trabajo': sentidos, clasificaciones y distinciones en torno al trabajo entre jóvenes de clases populares en Córdoba (PhD Thesis). National University of Cordoba, Cordoba, Argentina. Unpublished.

Assusa, G. (2017). Jóvenes trabajadores: Disputas sobre sentidos, apropiaciones simbólicas y distinciones sociales en el mundo laboral. Buenos Aires, Argentina: Grupo Editor Universitario.

Balardini, S., \& Miranda, A. (2000). Juventud, transiciones y permanencias. Pobres, pobreza y exclusión social. Buenos Aires, Argentina: CEIL/CONICET.

Battistini, O. (2009). La precariedad como referencial identitario. Un estudio sobre la realidad del trabajo en la Argentina actual. Psicoperspectivas, VIII(2), $120-142$.

Bayón, M. C. (2015). La Integración excluyente. Mexico City, Mexico: Bonilla Artigas/IISUNAM.

Beccaria, L., Carpio, J., \& Orsatti, A. (2000). Argentina: informalidad laboral en el nuevo modelo económico. In J. Carpio, E. Klein, \& I. Novacovsky (Eds.), Informalidad y exclusión social (pp. 139-160). Buenos Aires, Argentina: FCE/ SIEMPRO/ILO.

Bendit, R., Hahn, M., \& Miranda, A. (2008). Los jópenes y el futuro. Procesos de inclusión social y patrones de vulnerabilidad en un mundo globalizado. Buenos Aires, Argentina: Prometeo.

Bendit, R., \& Miranda, A. (2015). Transitions to Adulthood in Contexts of Economic Crisis and Postrecession. The Case of Argentina. Journal of Youth Studies, 18(2), 183-196.

Benza, G. (2016). La estructura de clases argentina durante la década 2003-2013. In G. Kessler (Ed.), La sociedad argentina hoy (pp. 111-139). Buenos Aires, Argentina: Siglo XXI/Fundación OSDE. 
Bertranou, F., Jiménez, M., \& Jiménez, M. (2013). Informalidad, calidad del empleo y segmentación laboral en Argentina (Working Documents, 2). Buenos Aires, Argentina: ILO Country Office for Argentina.

Bravo Almonacid, F. (2015). Envejecer en la pobreza: Prácticas y representaciones de personas mayores tendientes a su reproducción cotidiana en ámbitos domésticos y extradomésticos (PhD Thesis). National University of La Plata, Buenos Aires, Argentina. Available from: http://www.memoria.fahce.unlp.edu.ar/tesis/ te.1354/te.1354.pdf

Busso, M., \& Pérez, P. (2016). Caminos al trabajo: el mundo laboral de los jóvenes durante la última etapa del gobierno kirchnerista. Buenos Aires, Argentina: Miño y Dávila.

Chaves, M. (2014a). Cotidianeidad juvenil en la pobreza: una lectura desde las desigualdades omnipresentes. In s/d, XI Argentine Congress of Social Anthropology, National University of Rosario. Rosario, Argentina.

Chaves, M. (2014b). Haciendo trámites con los pibes y las familias: barreras de acceso y micropolíticas públicas. Escenarios, 14(21), 15-23.

Chaves, M. (2016) "El esfuerzo": usos en la construcción de fronteras, lógicas de merecimiento y redes de desigualdad con jóvenes de sectores populares en un barrio de La Plata. In M. Rozas Pagaza, III (Ed.), Latin American Social Work Forum. La Plata, Argentina: School of Social Work, National University of La Plata. Available: http://www.trabajosocial.unlp.edu.ar/uploads/docs/ chaves_gt_24.pdf

Chaves, M., Fuentes, S. G., \& Vecino, L. (2016). Experiencias juveniles de la desigualdad. Fronteras y merecimientos en sectores populares, medios altos y altos. Buenos Aires, Argentina: Grupo Editor Universitario. (2017) Edición Digital. Buenos Aires, Argentina: CLACSO-GEU. Available: http://biblioteca.clacso. edu.ar/clacso/gt/20171218041618/Experiencias_juveniles_de_la_desigualdad.pdf

Chávez Molina, E., \& Pla, J. (2013). Desigualdad y movilidad social en el mundo contemporáneo aportes empiricos y conceptuales: Argentina, China, España, Francia. Buenos Aires, Argentina: Imago Mundi.

Crego, M. L., \& González, F. (2015). Nuevas oportunidades como experiencia. Jóvenes y desigualdad en el caso del Plan FinEs2 en el Gran La Plata, Cuestiones de Sociología, 13. Retrieved from: http://www.cuestionessociologia.fahce.unlp. edu.ar/article/view/CSnl3a03

Crompton, R. (1997). Clase y estratificación. Una introducción a los debates actuales. Madrid, Spain: Tecnos.

Dubet, F. (2015). Por qué preferimos la desigualdad. Buenos Aires, Argentina: Siglo XXI.

Efron, R., Konterllnik, I., \& Jacinto, C. (1996). Adolescencia, pobreza, educación y trabajo: el desafía es hoy. Buenos Aires, Argentina: Editorial Losada.

Eguia, A., Ortale, M. S., Piovani, J., \& Weingast, D. (2007). La pobreza en Argentina: nuevas realidades, nuevos conceptos. In A. Camou, M. C. Torti, \& 
A. Viguera (Eds.), La Argentina democrática: los años y los libros (pp. 241-280). La Plata, Argentina: UNLP-Prometeo.

Eguia, A., \& Ortale, S. (2004). Reproducción social y pobreza urbana. Cuestiones de Sociología, 2: $\mathrm{s} / \mathrm{n}^{\circ}$. Retrieved from: https://www.cuestionessociologia. fahce.unlp.edu.ar/article/view/CSn02a01/5792

Elder, G. (1994). Time, Human Agency, and Social Change: Perspectives on the Life Course. Social Psychology Quarterly, 57(1), 4-15. doi: https://doi. org/10.2307/2786971. Stable URL: http://www.jstor.org/stable/2786971

Elder, G. (1998). The Life Course as Developmental Theory. Child Development, 69(1), 1-12. https://doi.org/10.2307/1132065.

Elder, G., Kirkpatrick Johnson, M., \& Crosnoe, R. (2003). The Emergence and Development of Life Course Theory. In J. T. Mortimer \& M. J. Shanahan (Eds.), Handbook of the Life Course (pp. 3-19). New York, NY: Kluwer.

Espinoza, V., \& Kessler, G. (2003). Movilidad social y trayectorias ocupacionales en Argentina: rupturas y algunas paradojas del caso de Buenos Aires. Santiago de Chile, Chile: CEPAL/ECLAC. Retrieved from: http://www.cepal.org/publicaciones/DesarrolloSocial/5/LCL1895PE/lcl1895eP.pdf

Féliz, M. (2012). Proyecto sin clase: crítica al neoestructuralismo como fundamento del neodesarrollismo. In AAVV. Más allá del individuo. Clases sociales, transformaciones económicas y politicas estatales en la Argentina contemporánea (pp. 7-44). Buenos Aires, Argentina: Editorial El colectivo.

Féliz, M. (2015). Argentina neodesarrollista: debates sobre el modelo. La Plata, Argentina: EDULP. Available at: http://www.memoria.fahce.unlp.edu.ar/ libros/pm.383/pm.383.pdf

Fernández Massi, M. (2014). Una mirada sectorial sobre las inserciones laborales precarias de los jóvenes en Argentina. In P. Pérez \& M. Musso (Coord.), Tiempos contingentes: inserción laboral de los jóvenes en la Argentina posneoliberal (pp. 33-52). Buenos Aires, Argentina: Miño y Dávila.

Ferreira, F., Messina, J., Rigolini, J., López Calva, L. F., Lugo, M. A., \& Vakis, R. (2013). Panorámica general: La movilidad económica y el crecimiento de la clase media en América Latina. Washington, DC: World Bank Latin American and Caribbean studies.

Gallart, M. A. (2001). El desafio de la formación para el trabajo de los jóvenes en situación de pobreza en el Gran Buenos Aires. Buenos Aires, Argentina: CENEP.

Goldthorpe, J. (2012). De vuelta a la clase y el estatus: por qué debe reivindicarse una perspectiva sociológica de la desigualdad social. Reis, 137, 43-58. https:// doi.org/10.5477/cis/reis.137.43.

González, F. (2014). Dinámicas desiguales de inserción laboral: Posiciones en el mundo del trabajo, estrategias de búsqueda y mecanismos de acceso a empleos en jóvenes estudiantes del Plan FinEs 2 en la ciudad de La Plata. In A. Viguera (Ed.), VIII Conference of Sociology of the National University of La Plata. Ensenada, Argentina. Available at: http://www.memoria.fahce.unlp.edu.ar/ trab_eventos/ev.4445/ev.4445.pdf 
Gorbán, D. (2014). Las tramas del cartón. Trabajo y familia en los sectores populares del Gran Buenos Aires. Buenos Aires, Argentina: GORLA.

Gutiérrez, A. (2007). Herramientas teórico-metodológicas de un análisis relacional para los estudios de la pobreza. Ciencia, docencia y tecnología (35), 15-33.

Gutiérrez, A. (2015). Pobre’... como siempre: Estrategias de reproducción social en la pobreza. Villa María, Argentina: Eduvim.

Hernandez, C., Cingolani, J., \& Chaves, M. (2015). Espacios con edades: el barrio y la pobreza desde los niños/as y jóvenes. In M. Chaves \& R. Segura (Eds.), Hacerse un lugar. Prácticas, circuitos y trayectorias juveniles en ámbitos urbanos (pp. 123-146). Buenos Aires, Argentina: Biblos.

International Labour Office. (2012). The Youth Employment Crisis: Time for Action. Retrieved from: http://www.ilo.org/wcmsp5/groups/public/\%2D $\% 2 \mathrm{D}$-ed_ norm/\%2D\%2D-relconf/documents/meetingdocument/wcms_175421.pdf

International Labour Organization. (2013). Global Employment Trends for Youth 2013 A Generation at Risk. Retrieved from: http://www.ilo.org/wcmsp5/ groups/public/@dgreports/@dcomm/documents/publication/ wcms_212423.pdf

Jacinto, C. (2002). Los jóvenes, la educación y el trabajo en América Latina. Nuevos temas, debates y dilemas. In M. Ibarrola (Ed.), Desarrollo local y formación: hacia una mirada integral de la formación de los jóvenes para el trabajo (pp. 67-102). Montevideo, Uruguay: CINTERFOR/ILO.

Jacinto, C., Wolf, M., Bessega, C., \& Longo, M. E. (2005). Jóvenes, precariedades y sentidos del trabajo. In $s / d 7^{\circ}$ National Congress of Labor Studies. Argentine Association of Specialists in Labor Studies, Buenos Aires, Argentina. Available at: http://www.aset.org.ar/congresos/7/02007.pdf

Kessler, G. (2014). Controversias sobre la desigualdad. Argentina, 2003-2013. Buenos Aires, Argentina: Fondo de Cultura Económica.

Labrunée, M. E., \& Gallo, M. E. (2005). Informalidad, precariedad y trabajo en negro. Distinción conceptual y aproximación empírica. Realidad Económica, 210, 60-76.

Macri, M., \& Van Kemenade, S. (1993). Estrategias laborales en jóvenes de barrios carenciados. Buenos Aires, Argentina: Centro Editor de América Latina.

Ministerio de Trabajo, Empleo y Seguridad Social de la Nación. (2017). Informe Jóvenes y trabajo. Buenos Aires, Argentina. Retrieved from http://www.trabajo.gob.ar/downloads/estadisticas/Jovenes_y_trabajo_2017.pdf

Miranda, A., \& Arancibia, M. (2017). El futuro está incompleto: la construcción de trayectorias laborales sobre principios de siglo 21. Trabajo y Sociedad, 28, 195-217.

Mora Salas, M., \& de Oliveira, O. (2014). ¿Ruptura o reproducción de las desventajas sociales heredadas? Relatos de vida de jóvenes que han vivido situaciones de pobreza. In M. Mora Salas \& O. de Oliveira (Coords.), Desafíos y paradojas. Los jóvenes frente a las desigualdades sociales (pp. 245-312). Mexico City, Mexico: El Colegio de México - Centro de Estudios Sociológicos. 
Noel, G. (2014). Presentación Las dimensiones morales de la vida colectiva. Exploraciones desde los estudios sociales de las moralidades. Papeles de Trabajo, $8(13), 14-32$.

O'Connor, E. A. (2009). El neodesarrollismo en la Argentina: un enfoque de desarrollo e integración regional (PhD Thesis). Argentine Catholic University, Buenos Aires, Argentina. Retrieved from: http://bibliotecadigital.uca.edu.ar/ repositorio/tesis/neodesarrollismo-argentina-enfoque-desarrollo.pdf

Observatorio de la Seguridad Social. (2011). Asignación universal por hijo para protección social: una politica de inclusión para los más vulnerables. Buenos Aires, Argentina: ANSES. Retrieved from: http://observatorio.anses.gob.ar/ archivos/documentos/AUH\%20para\%20Protecci\%C3\%B3n\%20Social.pdf

Palomino, H., \& Dalle, P. (2012). El impacto de los cambios ocupacionales en la estructura social de la Argentina: 2003-2011. Revista del Trabajo - Nueva Época, 8(10), 205-224.

Pérez, P. (2011). Jóvenes, estratificación social y oportunidades laborales. Lavborarios, 24, 134-153.

Pérez, P., \& Busso, M. (Eds.). (2014). Tiempos contingentes: inserción laboral de los jóvenes en la Argentina posneoliberal. Buenos Aires, Argentina: Miño y Dávila ediciones.

Pérez, P., \& Busso, M. (2015). Los jóvenes argentinos y sus trayectorias laborales inestables: Mitos y realidades. Trabajo y sociedad (24), 147-160.

Piecke Goicochea, E. (2001). Los jóvenes y el trabajo: la educación frente a la exclusión social. Mexico City, Mexico: Universidad Iberoamericana.

Pla, J., \& Chávez Molina, E. (2010a). Mobility or Social Reproduction in a Poor Quarter of Buenos Aires. In Spring Meeting of the Research Committee on Social Stratification and Mobility (RC28) of the International Sociological Association. Haifa, Israel.

Pla, J., \& Chávez Molina, E. (2010b). Determinantes de la movilidad social de un barrio periférico del Gran Buenos Aires. In II International Encounter Political Theory and Practice in Latin America. National University of Mar del Plata, Mar del Plata, Argentina. CD-ROM.

Quartulli, D., \& Salvia, A. (2012). La movilidad y la estratificación socio-ocupacional en la Argentina. Un análisis de las desigualdades de origen. Entramados $y$ perspectivas, 2(2), 15-42.

Racynski, D., \& Serrano, C. (1985). Vivir la pobreza. Testimonio de mujeres. Santiago de Chile, Chile: PISPAL-CIEPLAN.

Reygadas, L. (2004). Las redes de la desigualdad: un enfoque multidimensional. Politica y Cultura, 22, 7-25.

Rivas Rivas, R. (2008). Dos enfoques clásicos para el estudio de la estratificación social y de las clases sociales. Espacio Abierto, 17(3), 367-389.

Roberti, E. (2016). Los sentidos (des)centrados del trabajo: hacia una reconstrucción de los itinerarios típicos delineados por jóvenes. Ultima década, 24(44), 227-255. 
Salvia, A., \& Lindenboim, J. (2015). Hora de Balance: proceso de acumulación, mercado de trabajo y bienestar. Argentina 2002-2014. Buenos Aires, Argentina: EUDEBA.

Saraví, G. (2006). Biografías de exclusión: desventajas y juventud en Argentina. Perfiles Latinoamericanos, 28, 83-116.

Saraví, G. (2009). Transiciones vulnerables: juventud, desigualdad y exclusión en México. Mexico City, Mexico: CIESAS.

Saraví, G. (2015). Juventudes fragmentadas: socialización, clase y cultura en la construcción de la desigualdad. Mexico City, Mexico: FLACSO-CIESAS.

Therborn, G. (2015). Los campos de exterminio de la desigualdad. Buenos Aires, Argentina: Fondo de Cultura Económica.

Tilly, C. (2000). La desigualdad persistente. Buenos Aires, Argentina: Manantial.

Vera, J. (2013). Informalidad y segmentación laboral desde la perspectiva estructuralista: una aplicación para la argentina (1992-2010). Lavboratorio, 25, $11-34$. 